\title{
The traditional and conventional medical treatment of cutaneous leishmaniasis in rural Ecuador
}

\author{
M. Margaret Weigel ${ }^{1}$ and Rodrigo X. Armijos ${ }^{2,3}$
}

ABSTRACT Objective. To explore the knowledge, beliefs, and practices (KBPs) regarding cutaneous leishmaniasis (CL) treatment held by an endemic population in Ecuador.

Methods. A follow-up to research done several years before, this study used random cluster sampling to select 529 adults who lived in rural northwestern Ecuador. Data were collected over a 24-month period using in-depth interviews supplemented with qualitative methods.

Results. Most of the subjects were familiar with CL. The interviewed persons described a large, diverse ethnomedical treatment inventory. Contrary to expectations, few treatment KBPs were predicted by gender, age, or prior CL experience. Factors reported as important in treatment decisions included female reproductive status, CL "type" (perceived form of the illness), lesion location, number of other infected household members, cost of the various treatments, treatment availability, and perceived treatment effectiveness. Subjects' strong motivation for prompt treatment appeared to be associated with beliefs regarding the inability of CL lesions to heal spontaneously, the disease's propensity to progress into fatal illnesses, and disfigurement. Despite increased familiarity with Glucantime ${ }^{\circledR}$ (meglumine antimonate), the conventional pentavalent antimonial drug used to treat CL in Ecuador, the proportion of subjects who had used it in their treatment remained low (20\%) while the prevalence of premature drug discontinuance appeared to have doubled in comparison to our earlier study.

Conclusions. By itself, increased access to Glucantime ${ }^{\circledR}$ is unlikely to increase usage of the drug and to reduce its frequent premature discontinuance unless public health planners accommodate the health and illness world views of local populations. Efficacy and safety studies should be undertaken to investigate promising traditional remedies as possible alternatives to Glucantime ${ }^{\circledR}$.

Key words Cutaneous leishmaniasis; traditional medicine; knowledge, attitudes, practices; Ecuador.

The incidence of cutaneous leishmaniasis (CL) is reported to be increasing in Latin America as well as in many other areas of the world (1). With CL and other diseases, the effectiveness of community disease control programs can be enhanced by a better understanding of how local ethnomedical

burg, Virginia 24061-0430, United States of America; e-mail:mweigel@vt.edu

2 Central University of Ecuador, College of Medicine, Graduate School of Basic Medical Sciences, Immunology Research Laboratory, Quito, Ecuador.

3 Ecuador, Ministry of Public Health, "Izquieta Pérez" National Hygiene Laboratory, Department of Microbiology, Quito, Ecuador. systems operate $(2,3)$. Familiarity with the world view and the disease and treatment knowledge, beliefs, perceptions, and practices of population groups has practical value. For example, such familiarity can be used to predict how individuals and families make decisions about CL diagnosis and treatment, including the factors that influence the timing and amount of treatment as well as the type of treatment received (e.g., "conven- 
tional" Western medical treatment, traditional treatment, or a mix of conventional and traditional treatment). This familiarity also can help identify potential barriers to conventional medical treatment as well as culturally acceptable alternative treatments of potential therapeutic value.

An earlier exploratory study that our research group conducted in an endemic area of subtropical northwestern Ecuador during 1989-1991 revealed that the majority of the adults in that area's agrarian population were well acquainted with CL and its sandfly vector (4). These subjects described an extensive ethnomedical inventory of topical CL treatments. Women identified more treatment methods than men did, but fewer than $10 \%$ of either gender group said they were familiar with Glucantime ${ }^{\circledR}$ (meglumine antimonate), the conventional pentavalent antimonial drug used to treat CL in Ecuador. Treatment with Glucantime ${ }^{\circledR}$ usually involves a number of days of intramuscular injection of $20 \mathrm{mg} \mathrm{Sb} /$ $\mathrm{kg} /$ day.

In our first study, $90 \%$ of subjects with recent or past CL reported that they had been treated for their infections. However, only $22.5 \%$ of them indicated that this treatment had included any antimonial drugs, and an even smaller proportion appeared to have received the recommended dose of the drug. No significant gender differences were identified regarding access to either conventional or traditional CL treatment.

The earlier study was informative, but its exploratory nature raised as many questions as it answered about the ethnomedical context of CL infection in the predominantly mestizo population. Questions also arose about how CL sufferers and the other members of their households make decisions about the allocation, timing, and type of treatment as well as the impact of gender, age, education, reproductive status, and prior disease experience of infected persons and family members (that is, having experienced CL themselves or having had another immediate family member afflicted). In order to address these new questions, we decided to conduct a follow-up study in the same area of northwestern Ecuador. Furthermore, since the time of the first study, the area had experienced considerable population growth due to in-migration as well as considerable political, economic, and infrastructure development, with new roads and new and improved electricity and municipal water services. Therefore, we wished to investigate whether these changes in the area had impacted CL treatment knowledge, beliefs, perceptions, and practices and/or had resulted in improvements in the population's access to conventional treatment.

\section{MATERIALS AND METHODS}

This new survey was conducted during a 24-month period, from June 1993 through June 1995, in the same subtropical region of northwestern Ecuador as the previous study (4). We used data from a 1992 census to estimate population size and to identify specific household sites. Using random cluster sampling, we selected a cohort of 529 adults, who comprised $15 \%$ of all the eligible adults aged $\geq 18$ years living in households in each of the 43 hamlets in the study area. Immediately after giving their informed verbal consent, subjects underwent a leishmanin skin test (LST) and a clinical history that included a comprehensive physical examination. Suspicious lesions were evaluated by aspirate culture and direct smear. Subjects with a positive parasitological diagnosis were classified as having an active infection. Those with a positive clinical history, who had characteristic dermal scarring, and a positive LST were classified as having prior CL.

In-depth interviews were conducted using a structured questionnaire that contained a mixture of closed-ended and open-ended questions. The questionnaire was administered during face-to-face verbal interviews with subjects in their homes or in an unoccupied community building, usually the local schoolhouse. Each interview was conducted in a private room or a cordoned-off area in order to maintain privacy and the confidentiality of the interviewees' responses.

The first part of the questionnaire collected information on the sociodemographic and other characteristics of the subjects. The second portion questioned subjects on their familiarity with CL. Subjects who reported being unfamiliar with the illness were excused from the remainder of the interview. The others (444 of the 529, or $83.9 \%$ of them) proceeded on to the third part of the interview, which explored specific aspects of their CL treatment knowledge, beliefs, and perceptions. Only the 293 subjects who had recent or prior CL proceeded to the fourth part of the interview. Of these 293, 281 of them (95.9\%) were able to describe their treatment history with respect to whether or not they had ever been treated for CL, the specific types and number of methods used, and the completeness of any Glucantime ${ }^{\circledR}$ therapy received. Other questions in this fourth part explored what factors had been involved in household-level decisions made about their treatment for CL.

Draft versions of the questionnaire were discussed first among study team members, local health workers, and community members in order to better clarify culture-specific terms and concepts. The instrument was field-tested in a pilot study in a nonparticipating village in the area, and individual items were refined as needed.

Using the final version of the questionnaire, experienced interviewers who were trained in its administration gathered the study data. Additional qualitative information was collected through nonparticipant observation and key-informant interviews. None of the selected subjects declined to participate in the study. However, 8 of the $529(1.5 \%)$ did not complete all of the interview for reasons they attributed to constraints related to family, work, or time. The larger project on which the study was "piggybacked" was approved by the Ethics Committee in the School of Medical Sciences of the Central University of Ecuador, in Quito. 


\section{Data Analysis}

The descriptive statistics reported included frequency, percent, and mean plus or minus the standard deviation. Three interval-level variables were assessed for their contribution to reported knowledge, beliefs, perceptions, and practices: residence in one of six cluster areas (Pedro Vicente Maldonado, Toachi, Río Guayabamba, San Miguel de los Bancos, Luz de América, and Puerto Quito), years of residence $(<1.0,1.0-4.9,5.0-9.9,10.0-14.9, \geq 15.0$ years), and reproductive status in women (pregnant, lactating, nonpregnant/nonlactating). The dichotomized variables were: subject CL history (positive vs. negative), reported immediate family member CL history (positive vs. negative), gender (female vs. male), ethnicity (mestizo vs. other), age ( $\leq 40$ vs. $>40$ years), formal education ( $\leq 6$ vs. $>6$ years), marital status (married vs. other), and monthly per capita income (local equivalent of $<$ US\$ 60 vs. $\geq$ US\$ 60). The SPSS for Windows statistical package version 10 (SPSS, Chicago, Illinois, United States of America) was used in the statistical analyses. Differences between proportions were examined using contingency table analysis with corrected chi-square $\left(\chi^{2}\right)$ or Fisher's exact test. The independent contribution of predictor variables identified as significant in the simple bivariate analyses were subsequently assessed with multiple logistic regression analysis. Adjusted odds ratios (ORs) and 95\% confidence intervals (CIs) were also calculated. Mean differences were investigated by Student's $t$ test and one-way analysis of variance. Notes obtained during the key-informant interviews were assessed using content analysis.

\section{RESULTS}

\section{Subject characteristics}

Table 1 shows the characteristics of the sample of 529 adults who participated in the survey. As shown, the majority of the participants were age

TABLE 1. Subject sociodemographic characteristics, leishmaniasis study, Ecuador, 1993-1995

\begin{tabular}{|c|c|c|}
\hline Characteristic & Number ${ }^{a}$ & $\%$ \\
\hline \multicolumn{3}{|c|}{ Length of residence in endemic area (yr) } \\
\hline$<1.0$ & 24 & 4.6 \\
\hline $1.0-4.9$ & 74 & 14.1 \\
\hline $5.0-9.9$ & 89 & 17.0 \\
\hline $10.0-14.9$ & 82 & 15.6 \\
\hline$\geq 15.0$ & 255 & 48.7 \\
\hline \multicolumn{3}{|l|}{ Ethnicity } \\
\hline Mestizo & 487 & 92.1 \\
\hline Other & 42 & 7.9 \\
\hline \multicolumn{3}{|l|}{ Sex } \\
\hline Female & 336 & 63.5 \\
\hline Male & 193 & 36.5 \\
\hline \multicolumn{3}{|l|}{ Age (yr) } \\
\hline$\leq 40$ & 362 & 68.8 \\
\hline$>40$ & 164 & 31.2 \\
\hline \multicolumn{3}{|c|}{ Per capita monthly income (US\$ equivalent) } \\
\hline$<\$ 60$ & 283 & 55.4 \\
\hline$\geq \$ 60$ & 228 & 44.6 \\
\hline \multicolumn{3}{|l|}{ Marital status } \\
\hline Legally married & 281 & 53.6 \\
\hline Common-law marriage & 150 & 28.6 \\
\hline Single & 72 & 13.7 \\
\hline Other & 21 & 4.1 \\
\hline \multicolumn{3}{|l|}{ Formal education (yr completed) } \\
\hline$<1$ & 46 & 8.7 \\
\hline $1-6$ & 419 & 79.7 \\
\hline$>6$ & 61 & 11.6 \\
\hline \multicolumn{3}{|c|}{ Reproductive status (women only) } \\
\hline Pregnant & 35 & 10.9 \\
\hline Lactating & 66 & 20.6 \\
\hline Nonpregnant, nonlactating & 219 & 68.4 \\
\hline
\end{tabular}

40 or younger, were married, were poorly educated, had low incomes, and were long-term residents of this endemic area. Two-thirds were female, of whom $32 \%$ were either pregnant or breastfeeding an infant at the time of the survey.

Of the 529 subjects, 30 of them (5.7\%) had active CL, and 263 of them $(49.7 \%)$ had evidence of prior infection. Men (61.6\%) were more likely than women $(47.7 \%)$ to show evidence of past $\mathrm{CL}(\mathrm{OR}=1.7,95 \% \mathrm{CI}=1.1-$ $2.5)$, but the men's risk for current infection was not significantly different from that of women. The reported prevalence of current and prior CL among the immediate family members (parents, siblings, spouse, and children) of the study subjects was also elevated.

\section{The ethnomedical context of leishmaniasis}

The majority of the subjects and key informants appeared to conceive of CL as an illness that was distinct from other dermatological diseases in terms of its physical characteristics and clinical evolution. The subjects and informants depicted a world view of health and illness that combined their reinterpretation of Western germ theory, elements of sixteenth-century Spanish Hippocratic humoral medicine, locally evolved folk beliefs, and fatalism. A total of three major "types" of CL were reported by the survey subjects and key informants. Each of the three was further described as consisting of two or three different subtypes, which can be differentiated on the basis of their 
specific clinical characteristics and outcomes, ranging from relatively benign to "dangerous." Many subjects and informants reported that any CL lesion that remains unhealed for a long time will eventually develop into fatal illnesses, especially skin cancer, gangrene, tetanus, leprosy, or other illnesses involving bone and tissue. This was said to happen more quickly in the case of the "more dangerous" forms of CL.

\section{Leishmaniasis treatment knowledge, beliefs, and perceptions}

Of the 529 subjects, $83.4 \%$ of them indicated that they were familiar with sarna brava (Spanish for "angry sore"), the most common local term for CL. Of these persons familiar with $\mathrm{CL}$, close to $85 \%$ of them reported that lesions cannot heal without some type of treatment. Nearly all (97\%) of these subjects also reported that they knew at least one method that was effective for healing CL lesions (mean $=1.6 \pm 1$ method). The total number of different treatment methods described exceeded 150 . Only $11 \%$ of the cited methods specifically identified Glucantime ${ }^{\circledR}$ by name although some $44 \%$ cited "injections or medical treatment given by injection or 'vaccines' (i.e., injections) administered by health care providers." The other methods all involved topical types of applications. These included lesion cauterization (3\%); application of acids (4.8\%); Neosporin and other creams, ointments, and other over-the-counter preparations $(12 \%)$; and various toxic agents (e.g., heavy metals, strong chemicals, veterinary products, and petroleum by-products) $(7 \%)$. Various types of plant preparations used to treat lesions accounted for $13 \%$ of cited methods, with various home remedies accounting for the remainder (5.2\%).

Many of the CL treatments cited were described by study subjects and informants as being "hot" or "strong" since they cause intense burning, stinging, or pain. Injections and certain topical methods with very "hot/ strong" or harsh characteristics (e.g., acids, petroleum by-products, veterinary products, heavy metals, and cauterization) were often ranked as being the most effective to rapidly heal CL lesions. Some persons noted that heating plants (e.g., medicinal herbs, plantain skins, saps, and resins) or other substances (e.g., battery acid, lead, and mercury) to high temperatures right before placing them on the le- sions can further increase their healing abilities.

Table 2 shows the 45 different plant species that the subjects identified as being used to treat CL. These included: 1) plants usually consumed as staple foods, 2) common herbal remedies usually consumed as teas when used to treat other illnesses, 3) plants used as general treatments for all ul-

TABLE 2. Plants reported as being used to treat cutaneous leishmaniasis, Ecuador, 1993-1995

\begin{tabular}{|c|c|c|}
\hline Local Spanish name & Tentative taxonomic designation & Plant part(s) used \\
\hline Verbena & Verbena litoralis & Leaves \\
\hline Tiatina; escoba & Escopaia edulcis & Leaves \\
\hline Mejorana & Mejorana hortensis & Leaves \\
\hline Matico & Aristeguieta glutinosa & Leaves \\
\hline Sangre de drago & Croton lechleri & Sap \\
\hline Llantén & Plantago major & Leaves \\
\hline Doña Juana & Adenostema fosbergi & Leaves \\
\hline Piojo negro & Not classified & Pulp \\
\hline Balsa & Ochoroma pyramidale & Sap \\
\hline Santa María & Tanacetum partenicra & Leaves \\
\hline Santa Juana & Not classified & Leaves \\
\hline Mama Juana & Not classified & Leaves \\
\hline Ruda & Ruta graveolens & Leaves \\
\hline Cuchara de montes & Not classified & Leaves \\
\hline Bálsamo peruano & Myroxylon pereirae & Sap? \\
\hline Malacarpa & Not classified & $?$ \\
\hline Manzanilla & Matricaria chamomilla & Flowers \\
\hline Geranio & Pelargonium odoratisimum & Leaves, flowers \\
\hline Yerba mora & Solanum nigrum & Leaves, fruit \\
\hline Camisola & Not classified & Leaves \\
\hline Hoja del sapo & Not classified & Leaves \\
\hline Tabaco & Nicotiana tabacum & Leaves \\
\hline Ají & Capsicum annum & Fruit \\
\hline Papaya & Carica papaya & Juice \\
\hline Perijil & Petroselinum sativum & Leaves \\
\hline Banana & Musa paradisiaca & Pulp, sap \\
\hline Naranja & Citrus sinensis & Peel, zest, juice \\
\hline Yuca & Manihot esculenta & Leaves \\
\hline Canela & Cinnamomum verum & Bark \\
\hline Caña de azucar & Saccharum officinarum & Stalk \\
\hline Ciruela & Prunus sp. & Fruit \\
\hline Pan de arbol & Artocarpus altilis & Fruit \\
\hline Plátano & Musa paradisiaca & Sap, leaves, peel \\
\hline Lechuga & Lactuca sativa & Leaves \\
\hline Limón & Citrus aurantifolia & Juice, peel \\
\hline Cebolla & Allium cepa & Flesh \\
\hline Achiote & Bixa orellana & Seeds, leaves \\
\hline Ajo & Allium sativum & Fruit, seeds \\
\hline Cacao & Theobroma cacao & Fruit \\
\hline Piñón & Jatropha curcas; J. congeneres & Sap \\
\hline Copal & Dacryodes peruviana & Sap \\
\hline Comachella & Not classified & Sap \\
\hline Palo santo & Bursera graveolens & Sap \\
\hline Camacho & Xanthosoma sagitifolium & Sap \\
\hline Panbil & Iriartea deltoidea & $?$ \\
\hline
\end{tabular}


cers and wounds, and 4) plants specifically used to treat CL lesions.

Five primary methods were used to prepare the plants for the topical treatment of CL lesions. With one method, fresh plant leaves were heated until dry and crumbly. They were then pounded to produce a fine powder that was mixed with thick ointments or pomades to improve adhesion to lesions. Sometimes dry antibiotic powders were added to the mixture to enhance healing and decrease the risk of secondary infections. With a second method, fresh plant leaves, fruits, flowers, or seeds were boiled in water. While warm or at room temperature, the liquid was used to wash the lesions. With a third method, plants were burned at high temperatures to produce white-hot ashes, which were immediately applied to the open lesions. In a fourth method, plantain skins, thick plant leaves, annatto (Bixa orellana) seeds, or other plant parts, plant resins, or saps were heated to high temperatures and then placed on top of or dripped into the CL lesions. With the fifth method, the undiluted juice, zest, and other plant secretions from citrus and other fruits, garlic, onions, and plantain stalks were squeezed into the open lesions.

\section{Predictors of treatment knowledge}

We examined various predictors of the treatment knowledge reported by the subjects. The mean number of specific treatments that men reported they knew $(1.6 \pm 0.9)$ was not significantly different from that of their female counterparts $(1.7$ identified \pm 1.1$)(P>0.05)$.

However, men were twice as likely as women to report believing that harsh conventional and traditional treatments were more effective in healing CL lesions in comparison to medicinal plant washes and other milder methods $(10.3 \%$ vs. $4.8 \%$; OR = $2.3,95 \% \mathrm{CI}=1.1-4.9)$. On the other hand, a number of the factors measured did not significantly predict whether or not subjects reported that they knew any treatment methods, which ones they identified, or how many they mentioned. Among these nonpredicting characteristics were subject or family CL experience, age, residence, and the other sociodemographic indicators.

\section{Treatment beliefs}

The demand for CL treatment appeared high in this endemic population. Much of the demand appeared to be linked with a common beliefreported by $89 \%$ of all subjects in the study who said that they were familiar with CL-that the lesions cannot heal without treatment. Another frequently reported belief was that certain types of CL, especially ones that remain unhealed, can eventually evolve into skin cancer, leprosy, tetanus, gangrene, or such other potentially fatal diseases as tuberculosis or ones involving the bones. For these reasons, the subjects reported that fast-acting treatments are preferred. This was said to be especially important for those unlucky individuals infected with the "more dangerous" CL types or subtypes. Likewise, treatments that limit the size, depth, and spread of lesions and the scars they leave were also said to be preferred.

The simple bivariate analyses were unable to identify any significant associations between the reported subject beliefs and gender, CL experience, age, education, and the other sociodemographic indicators measured in the study.

\section{Treatment decision-making}

Gender is known to be a factor that can influence treatment access. Therefore, we questioned the study subjects as to whether gender would influence any decisions that they might make about their own CL treatment or that of other family members. Most of the subjects reported that neither the gender of adults $(77 \%)$ nor of children $(84.1 \%)$ would be an important consideration. These respondents reasoned that since the disease is the same for everyone, treatment should also be the same. In contrast, the minority of sub- jects who disagreed said that adult males and boys were better able to tolerate "hotter/stronger" methods compared to women and girls, by virtue of their more robust physical and emotional constitutions.

The results of the bivariate analyses revealed that the responses of subjects regarding whether an individual's gender should affect their treatment for CL was not predicted by the subjects' disease history, gender, education, ethnicity, or other characteristics measured. With age, however, subjects aged $>40$ years were twice as likely as their younger counterparts to report that boys and girls should get different types of CL treatment $(\mathrm{OR}=$ $2.2 ; 95 \% \mathrm{CI}=1.0-4.6)$. On the other hand, older subjects ( $>40$ years) did not differ regarding the treatment of adult males and females.

Female reproductive status is another variable often reported to restrict health care access. For that reason, the study subjects were questioned as to whether or not pregnant or nursing women infected with CL should be treated, and, if so, by what method or methods. Three-quarters of the respondents said this group of women should not be treated at all, or at most with only the mildest topical remedies available. They reasoned that "hot/ strong" methods can harm the developing fetus and/or the mother. The respondents specifically linked injections and other harsh CL treatments to adverse maternal and perinatal outcomes, including miscarriage, stillbirth, mental retardation, physical defects, low birthweight, premature delivery, labor and delivery difficulties, and maternal demise. Likewise, many of the respondents also reported that such treatments can spoil or otherwise damage breast milk and/or harm nursing infants by causing fevers, diarrhea, vomiting, delayed development, or dental damage. However, the simple bivariate analysis was unable to identify any significant associations between these reported treatment beliefs and the subjects' gender, age, education, CL experience, reproductive status (women only), or other indicators. 
The subjects were also asked about how they would prioritize treatment for the different members of a hypothetical family, all of whom were afflicted simultaneously with CL. This exercise was undertaken to gain additional insight into treatment inequities that may occur within the household unit and that are related to gender, age, or other factors. This is an important question since simultaneous infection of multiple family members is common in the study area and often makes it necessary for households to make difficult decisions about who will get treatment, how quickly they will be treated, and with which methods. Fifty-eight percent of the subjects said that they would treat all affected family members exactly the same by equally dividing whatever methods were available since to do otherwise would be discriminatory. Another $27 \%$ of the subjects indicated they would give infants and other young children first preference due to their decreased pain tolerance and increased emotional vulnerability. Most of the remainder reported that the adult male head of household should be treated first due to that person's importance as the primary cash wage earner. However, a small fraction said that mothers should be treated first, provided that they weren't pregnant or lactating, in order to set a good example for their children by first undergoing the physically painful Glucantime $^{\circledR}$ injections.

The bivariate analyses revealed that subjects whose households contained at least one family member with a positive CL history were significantly more likely $(63.1 \%)$ than others $(50 \%)$ to report that they would give treatment equally $(\mathrm{OR}=1.71,95 \% \mathrm{CI}=$ 1.07-2.74). On the other hand, older subjects ( $>40$ years) were nearly twice as likely as others to indicate that younger family members deserved preference (35.4\% vs. $27.1 \%$; OR $=1.97$, $95 \% \mathrm{CI}=1.26-3.1)$.

\section{Treatment practices}

Treatment history data were available for 281 (95.9\%) of the 293 subjects with a positive CL history. A total of 243 of the $281(86.5 \%)$ reported that they had been treated for their illness using one or more different methods (mean = $1.8 \pm 1.1$ methods; range, $1-7$ methods). Table 3 shows the distribution of treatments reported in this study. The large majority of these involved traditional remedies rather than conventional, Glucantime ${ }^{\circledR}$ treatment. The traditional, mostly topical applications included cauterization with very hot or cold objects or substances, plant preparations, over-thecounter ointments and creams, antibiotics, common household chemicals, battery acid, heavy metals, veterinary products, and petroleum by-products. Table 3 also compares the results found in this study with those found some 5 years prior (4).

The issue of premature drug discontinuance was examined among those subjects who reported that they had been treated with Glucantime ${ }^{\circledR}$. As Table 4 shows, fewer than one-third of the persons in this, the second study appeared to have received a full course of treatment, according to either Ecuadorian Ministry of Public Health (MPH) convention or recommendations of the World Health Organization (WHO). This figure was lower than that reported in our first survey (Table 4).

Several different reasons were given by the subjects in the current study to explain their drug discontinuance. Some attributed it to the frequent Glucantime $^{\circledR}$ shortages at the local MPH clinic, which distributed the medicine free to patients, and/or a lack of cash to purchase the drug from private vendors. Others said that because lesion remission had begun they had stopped using the drug. Still others cited the painful injections and other unpleasant and debilitating antimonial drug side effects as being the reason.

The bivariate data analyses failed to identify any significant gender, age, or other predictors of whether or not the subjects reported that their CL had been treated, the methods used (traditional vs. conventional vs. mixed), or the total number of different methods employed in their treatment. Likewise, no significant predictors were found with respect to whether subjects treated with Glucantime ${ }^{\circledR}$ appeared to have received a complete versus partial drug course nor the reasons, if any, that they gave to explain their premature discontinuance of the drug.

Treated subjects and key informants were questioned in further detail regarding how decisions had been made about their CL treatment. Many mentioned that knowledgeable family members, friends, and neighbors had been consulted for treatment advice. Specific decisions about which method to use were reported to have been influenced by CL type, lesion location, and, in some instances, age, gender, and/or reproductive status. The other factors that were reported to have influenced treatment included the perceived prior success or failure of methods that had been used by others, cost

TABLE 3. Reported leishmaniasis treatment practices in Ecuador, in current study (1993-1995) vs. prior study (1989-1991)a

\begin{tabular}{|c|c|c|c|c|}
\hline \multirow[b]{2}{*}{ Treatment category } & \multicolumn{2}{|c|}{$\begin{array}{l}\text { Current study } \\
\text { (243 subjects) }\end{array}$} & \multicolumn{2}{|c|}{$\begin{array}{l}\text { Prior study } \\
\text { (171 subjects) }\end{array}$} \\
\hline & No. & $\%$ & No. & $\%$ \\
\hline Traditional methods onlyb & 192 & 79.0 & 132 & 77.2 \\
\hline Glucantime ${ }^{\circledR}$ only & 37 & 15.2 & 22 & 12.9 \\
\hline Combined methods ${ }^{c}$ & 14 & 5.8 & 17 & 9.9 \\
\hline
\end{tabular}


TABLE 4. Reported completeness of antimonial drug treatment in Ecuador, according to institutional convention or recommendations, in current study (1993-1995) vs. prior study $(1989-1991)^{a}$

\begin{tabular}{|c|c|c|c|c|c|c|}
\hline & \multicolumn{4}{|c|}{ Current study ${ }^{b}$} & \multirow{2}{*}{\multicolumn{2}{|c|}{$\begin{array}{c}\text { Prior study } \\
\mathrm{MPH}^{\mathrm{c}}\end{array}$}} \\
\hline & \multicolumn{2}{|c|}{$\mathrm{MPH}^{\mathrm{c}}$} & \multicolumn{2}{|c|}{$\mathrm{WHO}^{\mathrm{d}}$} & & \\
\hline & No. & $\%$ & No. & $\%$ & No. & $\%$ \\
\hline Incomplete Glucantime ${ }^{\circledR}$ treatment & 31 & 67.3 & 42 & 91.3 & 15 & 38.5 \\
\hline Complete Glucantime $^{\circledR}$ treatment & 15 & 32.6 & 4 & 8.7 & 24 & 61.5 \\
\hline
\end{tabular}

a Results of prior study are from Weigel et al. (4).

${ }^{b}$ For the current study, this table shows the data only for the 46 persons who could specify the dosage and the length of their Glucantime ${ }^{\circledR}$ treatment; the table omits data on 5 persons who could not specify the dosage or length of their treatment.

c Former Ministry of Public Health dosage convention of $10 \mathrm{mg} / \mathrm{kg}$ body weight, administered for 10 days via intramuscular route.

${ }^{\mathrm{d}}$ World Health Organization recommendations of $20 \mathrm{mg} / \mathrm{kg}$ body weight administered for 10 days via intramuscular route (31).

and availability, and how many other family members were also affected at the time. Most of the persons who said that they had been treated with more than one method indicated that these had been utilized in a consecutive rather than concurrent manner. They also reported that in those instances where the lesion had worsened or satellite lesions had appeared, progressively "hotter/stronger" methods were used until satisfactory healing was observed.

\section{DISCUSSION}

This study confirmed that the endemic Ecuadorian group was highly motivated to seek treatment for CL infection. Most subjects with current or past CL reported that they received some form of treatment for their lesions. This finding is consistent with what we and other authors have reported previously for the same (4) and other nearby Ecuadorian (5) and Colombian populations $(6,7)$. The strong treatment demand appears to come from a belief held by many of the subjects that if persons infected with CL are not treated immediately then their lesions will continue to enlarge and spread. This finding concurs with that reported earlier for the same area (4) and for other endemic groups in Ecuador (5) and in Guatemala (8). Another common belief is that not only do lesions fail to heal without treatment but that untreated lesions can progress into more serious and potentially fatal illnesses that destroy soft tissue and bone, such as gangrene, skin cancer, tetanus, and leprosy. Similarly, Arana and colleagues (8) have noted that the rural Guatemalans they studied believe that untreated CL lesions can progress to involve bone. The Ecuadorian subjects also reported prompt treatment as being necessary to minimize the physical disfigurement caused by the unsightly lesions themselves as well as the permanent scars they leave. Disfigurement caused by CL lesions and scars has been reported as being linked with shame, embarrassment, low self-esteem, and stigma, particularly for women and girls $(4,5$, $9,10)$. These findings are similar to what has been reported for females afflicted with leprosy and other disfiguring tropical diseases (11-14).

The large size and diversity of the study population's ethnomedical inventory may be their way of responding to the frequent variation observed in the clinical outcomes of individuals treated for CL by the same and different methods. It could also be due to the apparent lack of recognition of many persons that CL lesions can heal spontaneously as well as these persons' limited access to conventional antimonial drug treatment. Many of the traditional CL treatments reported as used by the Ecuadorian group-for example, the use of cauterization, hot liquids, heavy metals, and bitter/acidic plants-are similar to those reported as used by historical Amerindian groups $(15,16)$ and by contemporary groups in Ecuador (4,
$5,17,18)$, Colombia $(6-8,19)$, and Brazil (20). Some of these and other folk remedies have the potential to disrupt parasite $\mathrm{pH}$, membranes, or metabolism. Given their potential clinical merit, these remedies warrant further investigation (21-24). However, the application of such substances as battery lead, thermometer mercury, herbicidal agents, and petroleum by-products to open lesions is contraindicated and should be discouraged due to their toxicity and the potential for damage to soft tissue and bone and for profound scarring.

Familiarity with conventional antimonial treatment appeared to have increased during the 5 years between our two studies. Nevertheless, the proportion of subjects who reported that the drug had been used in their own treatment remained relatively low, around $20 \%$. This indicates that despite the economic development that had taken place in the area since the first survey, there was no significant improvement in the group's limited access to conventional treatment. The low prevalence of antimonial drug usage is consistent with that reported for nearby groups living on the Pacific coast of Ecuador (5) and Colombia $(6,7)$.

In addition, the present investigation not only confirmed the frequent practice of premature discontinuance of Glucantime ${ }^{\circledR}$ in the area but also suggested that the practice had increased since the earlier study. The proportion of subjects in this study who reported receiving a complete treatment course, according to either $\mathrm{MPH}$ convention or WHO recommendations, was about half that found in the first study (4). The reasons for this increase in premature Glucantime ${ }^{\circledR}$ discontinuance are not immediately evident. However, they may be linked to more frequent shortages of the drug in the public health system and the drug's increased price on the private market, similar to the situation with other pharmaceutical products in the country. The practice of premature Glucantime ${ }^{\circledR}$ discontinuance has also been reported as being common in a nearby Ecuadorian population (5), and anecdotal evidence suggests that this may also be commonplace in other en- 
demic provinces. This practice has potential public health importance since inadequate antimonial treatment has been implicated in the development of drug-resistant parasite strains $(25,26)$ and recurrent infection, including late mucosal metastasis $(27,28)$.

Subject age and prior disease experience were found to predict the decisions that adults said that they would make regarding their own CL treatment or that of other immediate family members. The contention of most subjects that they would give equal treatment to all the persons in their family regardless of age or gender is supported by our field observations. The typical strategy in households with multiple affected members is to treat all members in exactly the same manner. In cases where Glucantime ${ }^{\circledR}$ is used, we have observed that most families divide up whatever they can obtain of this expensive drug and administer it in equal portions to each person. The one exception to this practice is in the case of pregnant and lactating women. The use of Glucantime ${ }^{\circledR}$, other types of injections, or other "strong" treatments in these women is prohibited due to the correct perceptions that these types of treatment can cause damage to the fetus or young infant.

Relatively few authors have examined the role of gender on reported CL treatment knowledge, beliefs, and practices and treatment access in endemic Latin American populations. In this study, men reported being more familiar with more toxic forms of treatment but did not necessarily know a greater number of traditional treatments overall than women did. This finding contrasts with Isaza and colleagues (6), who reported that men in a coastal Colombian population were more likely than women to be familiar with traditional forms of treatments. However, no other significant gender differences were found in either our study or the one by Isaza et al. with respect to treatment knowledge, beliefs, and practices and treatment access. Our results differ from those from some other studies of other Latin American groups $(7,29,30)$, which reported that women self-treated with traditional remedies more frequently than did men and that the women were less likely to be treated with Glucantime ${ }^{\circledR}$ and/or were treated much later in the course of their illness. The explanations for why our results and those of Isaza et al. (6) differ from those of the other authors are not immediately evident. Possibly there were differences in study design and methodology, the various populations' CL risk and experience, culturally dictated gender roles, or treatment traditions. In contrast, both of our Ecuador studies confirmed that despite the gender inequalities suffered by women in other areas of their lives, they did not appear to have restricted access to either conventional or traditional forms of CL treatment, and they were not less likely to have received a complete course of Glucantime $^{\circledR}$ treatment.

This study contains some potential biases that may influence the validity of the results. First, women were somewhat overrepresented in the sample. This may be the result of simple random sampling error. However, it seems more likely to have occurred because women were more likely to be present for data collection than were adult males, who frequently worked or traveled some distance away from their homes and communities. On the other hand, the number of men who were interviewed, 193, appeared adequate, and the results were fairly consistent with those from the first survey, where the gender ratio was more nearly equal (4).

Self-reported data obtained from structured interviews have limitations since there may be significant underreporting or overreporting of information, depending on whether the reported knowledge, beliefs, perceptions, or practices are thought to be desirable or undesirable. However, this study was piloted carefully, the interviewers were well trained in the methods of data collection used, and the interviewers were already accepted by the local communities. We also were prudent to conduct the interviews in private, away from other adult family members, friends, and neighbors. Refusals were rare, and we found that the subjects and the key informants appeared quite willing and open to answering the questions. Furthermore, there was close agreement on the answers to similar questions posed in this and our prior study, thus lending further support to the validity of the data in this study.

This study confirmed that the endemic Ecuadorian population was quite familiar with CL and its treatment. Their reported beliefs regarding the adverse physical and psychosocial consequences of untreated lesions appeared to be strong motivators for seeking prompt treatment. However, despite an apparent increase in familiarity with Glucantime ${ }^{\circledR}$ treatment compared to some 5 years before, the proportion of persons who had actually used the drug to treat their past or current CL infection was still relatively low. Almost $80 \%$ reported having used only traditional remedies for their treatment. Furthermore, the prevalence of premature drug discontinuance seemed to have almost doubled compared to the prior study. This is worrisome since inadequate antimonial treatment has been implicated in the development of drug-resistant parasite strains and recurrent infection. The low prevalence of Glucantime ${ }^{\circledR}$ therapy and high prevalence of premature Glucantime ${ }^{\circledR}$ discontinuance appeared to be the consequence of multiple factors. Increasing the supply of free or low-cost Glucantime ${ }^{\circledR}$ is unlikely given the current financial situation of Ecuador. Further, increased drug supplies alone are unlikely to change these persons' treatment practices unless public health planners also accommodate their world views of illness and health. We also recommend that investigators undertake efficacy and safety studies of some of the more promising traditional remedies used by local populations as possible future alternatives to Glucantime ${ }^{\circledR}$.

Acknowledgements. This research was supported in part by the Small Grants Program of the Laboratory of Social Sciences at the Central University of Venezuela \#SG-P93.162 and \#USAID 518-0058EXT. 


\section{REFERENCES}

1. World Health Organization. The leishmaniases and Leishmania / HIV co-infections Geneva: WHO; 2000. Available from: http://www.who. int. Accessed 2 January 2001. (WHO Fact Sheet No.116).

2. Manderson L. Applying medical anthropology in the control of infectious disease. Trop Med Int Health 1998;3(12):1020-1027

3. Manderson L. Social science research in tropical disease. Med J Aust 1994;160(5):289-292

4. Weigel MM, Armijos RX, Racines RJ, Zurita C, Izurieta R, Herrera E, et al. Cutaneous leishmaniasis in subtropical Ecuador: popular perceptions, knowledge, and treatment. Bull Pan Am Health Organ 1994;28(2):142-155.

5. Weigel MM. The cutaneous leishmaniasis knowledge, attitudes, and practices of Ecuadorian mestizo and Afro-Hispanic women. Geneva: Special Programme for Research and Training in Tropical Diseases; 1996.

6. Isaza DM, Restrepo BN, Arboleda M, Casas E, Hinestroza $\mathrm{H}$, Yurgaqui T. La leishmaniasis: conocimientos y prácticas en poblaciones de la costa del Pacífico de Colombia. Rev Panam Salud Publica 1999;6(3):177-184.

7. Velez ID, Hendrickx, Robledo SM, Agudelo S. Leishmaniosis cutánea en Colombia y género. Cad Saude Publica 2001:17(1):171-180.

8. Arana BA, Rizzo NR, Navin TR, Klein RE, Kroeger A. Cutaneous leishmaniasis in Guatemala: people's knowledge, concepts and practices. Ann Trop Med Parasitol 2000; 94(8):779-786.

9. Weigel MM, Armijos RX. Gênero e leishmaniose cutânea no Equador rural: risco de doença, gravidade e conseqüências. In: Barata RB, Briceno-Leon R, eds. Doenças endêmicas: abordagens sociais, culturais e compartimentais. Rio de Janeiro: Fundação Oswaldo Cruz; 2000. pp. 213-230

10. Castes M, Jimenez M, Castaneda N. Estudio de los aspectos epidemiológicos y socioeconómicos en mujeres con Leishmaniasis. Fermentum: Revista Venezolana de Sociología y Antropología 1993;2(4):85-98.

11. Paz CI, Medina IR, Ventura ER. A multidisciplinary study of stigma in relation to Hansen's disease among the Tausug in the Philippines. Geneva: Special Programme for Research and Training in Tropical Diseases;
1990. (TDR Social and Economic Research Project Report No. 7)

12. Ulrich M, Zulueta AM, Caceres-Dittmar G. Leprosy in women: characteristics and repercussions. In: Wijeyarante P, Rathgeber E, St. Onge $\mathrm{P}$, eds. Women and tropical diseases. Ottawa and Geneva: International Development Research Centre/Special Programme for Research and Training in Tropical Diseases; 1992. pp. 5-23.

13. Boonmongkon P. Khi thut, "the disease of social loathing": an anthropological study of the stigma of leprosy in rural north-east Thailand. Geneva: Special Programme for Research and Training in Tropical Diseases; 1995. (TDR Social and Economic Research Report No. 16).

14. Coreil J, Mayard G, Louis-Charles J. Filarial elephantiasis among Haitian women: social context and behavioural factors in treatment. Trop Med Int Health 1998;3(6):467-473.

15. Garcia-Kutzbach A. Medicine among the ancient Maya. South Med J 1976;69(7):938-940.

16. Estrella E. Medicina aborigen. Quito, Ecuador: Editorial Epoca; 1977.

17. Kroeger A, Macheno M, Estrella E. Malaria y leishmaniasis cutánea en Ecuador. Quito: Museo Nacional del Ministerio de Salud Pública/Universidad Central del Ecuador; 1993.

18. Amunarriz M. Salud y enfermedad. Patología tropical en la región amazónica ecuatoriana. Quito: Centro de Investigaciones Culturales de la Amazonía Ecuatoriana (CICAME); 1984.

19. Vásquez ML, Kroeger A, Lipowsky R, Alzate A. Conceptos populares sobre la leishmaniasis cutánea en Colombia y su aplicabilidad en programas de control. Bol Oficina Sanit Panam 1991;110(5):402-412.

20. França F, Lago EL, Marsden PD. Plants used in the treatment of leishmanial ulcers due to Leishmania (Viannia) braziliensis in an endemic area of Bahia, Brazil. Rev Soc Bras Med Trop 1996;29(3):229-232

21. Sharquie KE, Najim RA, Farjou IB. A comparative controlled trial of intralesionallyadministered zinc sulfate, hypertonic sodium chloride and pentavalent antimony compound against acute cutaneous leishmaniasis. Clin Exp Dermatol 1997;22(4):169-173.
22. Ali SA, Iqbal J, Khalil Y, Manzoor A, Bukhari I, Ahmad B, et al. Leishmanicidal activity of Nystatin (mycostatin): a potent polyene compound. J Pak Med Assoc 1997;47(10):246-248.

23. Akendengue B, Ngou-Milama E, Laurens A, Hocquemiller R. Recent advances in the fight against leishmaniasis with natural products. Parasite 1999;6(1):3-8

24. Fournet A, Barrios AA, Munoz V. Leishmanicidal and trypanocidal activities of Bolivian medicinal plants. J Ethnopharmacology 1994; 41(1-2):19-37.

25. Berman JD. Treatment of New World cutaneous and mucosal leishmaniases. Clin Dermatol 1996;14(5):519-522.

26. Grogl M, Thomason TN, Franke ED. Drug resistance in leishmaniasis: its implication in systemic chemotherapy of cutaneous and mucocutaneous disease. Am J Trop Med Hyg 1992;47(1):117-126.

27. Marsden PD. Mucosal leishmaniasis due to Leishmania (Viannia) braziliensis $\mathrm{L}(\mathrm{V}) \mathrm{b}$ in Três Braços, Bahia, Brazil. Rev Soc Bras Med Trop 1994;27(2):93-101.

28. Marsden PD. Mucosal leishmaniasis ("espundia" Escomel, 1911). Trans R Soc Trop Med Hyg 1986;80(6):859-876.

29. Vélez ID, Hendrickx E, Roman O, Agudelo S. Gender and leishmaniasis in Colombia: a redefinition of existing concepts. Geneva: Special Programme for Research and Training in Tropical Diseases; 1997. (Gender and Tropical Diseases Resource Paper No. 3)

30. Dobles Ulloa A, Perriad C. Representaciones, actitudes y prácticas respecto a la leishmaniasis cutánea en la población del Cantón de Acosta, Provincia de San José, Costa Rica. Estudio antropológico exploratorio. Cad Saude Publica 1994;10(2):181-189.

31. World Health Organization. Control of the leishmaniases. Geneva: WHO, 1990. (Technical Report Series \#793).

Manuscript received 23 January 2001. Revised version accepted for publication on 2 August 2001. 
RESUMEN Objetivo. Investigar los conocimientos, creencias y prácticas relacionadas con el tratamiento de la leishmaniasis cutánea (LC) en una población de Ecuador donde la enfermedad es endémica.

\section{Los tratamientos médicos tradicional y convencional de la leishmaniasis cutánea en una zona rural de Ecuador}

Métodos. En este estudio de seguimiento de una investigación hecha hace varios años, se utilizó un muestreo aleatorio de grupos para seleccionar 529 adultos que vivían en una zona rural del noroeste de Ecuador. Los datos fueron obtenidos a lo largo de un período de 24 meses mediante entrevistas en profundidad, complementadas con métodos cualitativos.

Resultados. La mayoría de los individuos estaban familiarizados con la LC. Las personas entrevistadas describieron un largo y diversificado inventario de tratamientos médicos tradicionales. Al contrario de lo esperado, fueron pocos los conocimientos, creencias y prácticas que se pudieron predecir en función del sexo, la edad o la experiencia previa con la LC. Los factores considerados importantes en las decisiones terapéuticas incluyeron el estado reproductivo de las mujeres, el "tipo" de LC (la percepción de la forma de la enfermedad), la localización de las lesiones, el número de personas infectadas residentes en el hogar, el costo y la disponibilidad de diferentes tratamientos y la percepción de su eficacia. La fuerte motivación de las personas para buscar tratamiento parecía estar asociada con las creencias sobre la imposibilidad de curación espontánea de las lesiones, la propensión de la enfermedad a progresar hacia formas letales y la desfiguración. En comparación con el estudio anterior, hubo un aumento de la familiaridad con Glucantime ${ }^{\circledR}$ (antimoniato de meglumina), el fármaco convencional utilizado en Ecuador para tratar la LC, pero, a pesar de ello, la proporción de personas que lo utilizaron siguió siendo baja (20\%) y la prevalencia de la interrupción prematura del tratamiento pareció duplicarse.

Conclusiones. Es improbable que, por sí mismo, el aumento del acceso a Glucantime ${ }^{\circledR}$ incremente el uso del fármaco y reduzca la interrupción prematura del tratamiento, a no ser que los planificadores de la salud pública adapten sus intervenciones a los conceptos de la población local sobre la salud y la enfermedad. Se deberían realizar estudios de eficacia y seguridad para investigar la posibilidad de sustituir Glucantime ${ }^{\circledR}$ por algunos remedios tradicionales prometedores.

Course: epidemiology in action: intermediate methods

\author{
Dates: $\quad 25$ February-1 March 2002 \\ Location: Emory University \\ Atlanta, Georgia, United States of America
}

The Centers for Disease Control and Prevention of the United States of America and Emory University will offer a course entitled "Epidemiology in Action: Intermediate Methods" at Emory University, in Atlanta, Georgia, United States. The course is designed for practicing public health professionals who have had training and experience in basic applied epidemiology and would like training in additional quantitative skills related to analysis and interpretation of epidemiologic data. The course will review the fundamentals of descriptive epidemiology and biostatistics and then cover measures of association, normal and binomial distributions, confounding, statistical tests, stratification, logistic regression, models, and computers as used in epidemiology.

A prerequisite for this course is an introductory course in epidemiology. The cost of tuition for the course is US\$ 500 , which does not include such other expenses as housing and meals during the course.

\author{
Information: \\ Emory University, International Health Department \\ 518 Clifton Road, N.E., Room 746 \\ Atlanta, Georgia 30322, United States of America \\ Telephone: (404) 727-3485 \\ Fax: (404) 727-4590 \\ E-mail: pvaleri@sph.emory.edu \\ Internet: http://www.sph.emory.edu/EPICOURSES/
}

